Original Research Paper

\title{
Distribution of Total Mercury in the Sedimentary Environment in Lake Ahémé, Southern Benin (West Africa)
}

\author{
${ }^{1,2}$ Julien Gnonlonfoun Adounkpe, ${ }^{1,3}$ N. B. Nadia Azon, ${ }^{1,3}$ Hermione W. Degila and ${ }^{3}$ Peace Hounkpe \\ ${ }^{1}$ Faculty of Agronomic Sciences, University of Abomey Calavi, Benin \\ ${ }^{2,3}$ Laboratoire des Sciences et Techniques de l'Eau de l'Institut National de l'Eau, Université d'Abomey-Calavi, Benin
}

\author{
Article history \\ Received: 19-08-2021 \\ Revised: 07-10-2021 \\ Accepted: 12-10-2021 \\ Corresponding Author: \\ Julien Gnonlonfoun Adounkpe \\ Faculty of Agronomic \\ Sciences, University of \\ Abomey Calavi, Benin \\ Email: julvictoire@yahoo.com
}

\begin{abstract}
This study focuses on the spatio-temporal assessment of mercury pollution of the sedimentary environment of Lake Ahémé in southwestern Benin Republic. Sediment samples were taken from 32 sites in July 2018 and then in December 2019, covering the two major climatic seasons of the southern area of the country. Sampling was done according to a grid design of the entire area of the ecosystem. The surface sediment samples were collected at a depth between 0 and $5 \mathrm{~cm}$ in three takes at each site with a Van Veen grab. Samples were frozen, lyophilized at $-40^{\circ} \mathrm{C}$, crushed, sieved and homogenized. The fraction less than $63 \mu \mathrm{m}$ in size was collected for the mercury determination by a Direct Mercury Analyser (DMA) operating by atomic absorption according to the US EPA 7473 method. The results obtained reveal that, in 2018, mercury is more concentrated in the northern and central part of the lake varying from $109 \mu \mathrm{g} / \mathrm{Kg}$ (center) to $132 \mu \mathrm{g} / \mathrm{Kg}$ (north) while in 2019, the central and southern zones of the lake were more concentrated in mercury, with 162 and $87 \mu \mathrm{g} / \mathrm{Kg}$ respectively. However, the values of the geo-cumulation index Igéo varies from 0 to 1 , showing that Lake Ahémé is slightly polluted at these sites.
\end{abstract}

Keywords: Pollution, Contamination, Mercury, Sediment, Lake

\section{Introduction}

Like most aquatic ecosystems, Lake Ahémé is influenced by human activities. It thus receives pollutants from the leaching of agricultural land located upstream (Amoussou, 2010; Dédjiho, 2014) and from domestic wastewater from neighboring villages (Dèdjiho, 2014). Previous studies on the environment have revealed metallic contamination $(\mathrm{Cu}, \mathrm{Zn}, \mathrm{Pb}$ and $\mathrm{Cd})$ of water and sediment matrices (Dimon et al., 2014; Chouti et al., 2017). They also revealed the beginning of lead, zinc and arsenic contamination of the sediments of the lakeside village of Agonsa (Dimon et al., 2014). These various contaminations seem to be linked, in general, with the poor management of household solid wastes and in particular with the discharge of wastewater from the Possotomè thermal plant with regard to zinc (Chouti et al., 2017). In fact, the polluting substances released into the aquatic ecosystem become part of the suspended matters, deposited in the sediments and then are released later into the lake water (Dimon et al., 2014). Given that lake Ahémé presents a certain richness in muddy faces and is subject to multiple pollution (Dimon et al., 2014; Chouti et al., 2017), its sedimentary environment becomes an interesting subject to study. Despite the various studies on trace metals of this ecosystem, it is no clear assessment of its mercury pollution. Thus, the present work is a continuation of the work already carried out and those in progress, to broaden the fields of investigation towards other metallic trace elements just as toxic such as mercury. This will involve (i) evaluating the distribution of total mercury over the entire extent of the lake, (ii) evaluating the influence of environmental parameters on the mercury content and (iii) identifying areas with probable Eco toxicological risk.

\section{Materials and Methods}

\section{Description of the Study Area}

Lake Ahémé is located in the southwest of Benin Republic between the parallels $6^{\circ} 20$ "and $6^{\circ} 40^{\prime \prime}$ North latitude and the meridians $1^{\circ} 55$ "and $2^{\circ} 1$ " East longitude (Fig. 1). It extends over a North East and South West orientation between Tokpa - Domè and Guézin and a North South orientation between Bopa and Tokpa Dome (Roche International, 2000). With a surface area of $8.500 \mathrm{ha}$, it ranks as the second largest lake in southern Benin after Nokoué. The body of water communicates upstream with the Couffo 
river and downstream with the Atlantic Ocean through the Ahô canal, which connects the lagoon of Ouidah and that of Grand-Popo.

Its hydrodynamics can be essentially classified into three phases:

> The first phase which corresponds to the onset of the rainy season in South Benin from February to May. This phase is characterized by a rapid increase in the salinity of the water, a slow rise in the water level, an almost zero flow from the Mono River and a very low yield from fishing

$>$ The second phase, which corresponds to the maximum of the wet season in the south of the country (from June to October). It is characterized by a rise in the water level of the lake, a drop in salinity and the rise of the Mono

$>$ The third phase, which lasts from November to January, corresponds to the beginning of the dry season in South Benin. It results in a drop in water level and a stabilized salinity stability and maximum fishing yields

\section{Sampling Strategies}

The sampling strategies have been described elsewhere (Azon et al., 2021). Succinctly, for a better appreciation of the spatial distribution of the mercury content in the sediments of Lake Ahémé, a grid of the environments was necessary to identify the number and location of sites to be sampled. Thus, a total of 32 lake sites equidistant from $1.65 \mathrm{~km}$ were sampled in July 2018 and in December 2019. Figure 2 the sediments were taken at a depth of between 0 and $5 \mathrm{~cm}$ using a Van Veen grab in three catches. by site. Each sample is collected in a polyethylene bag, labeled, stored at $4^{\circ} \mathrm{C}$ and transported to the laboratory.

\section{Pretreatments and Analyzes}

\section{Physic-Chemical Parameters}

In the laboratory, the composite samples are prepared according to an equal mass mixture of three samples per site. According to standard NF ISO 11464 , the sediments are lyophilized at $-40^{\circ} \mathrm{C}$, crushed, homogenized and sieved. The fraction which diameter is less than $2 \mathrm{~mm}$ was used to measure the physicochemical parameters: $\mathrm{pH}$ water, $\mathrm{eH}$ and organic matter. The fine fraction $(<63 \mu \mathrm{m})$ is recovered for the determination of mercury.

\section{Determination of Mercury}

The total mercury in the different samples was measured with the Direct Mercury Analyzer (DMA-80). The DMA-80 is an innovative instrument that allows the analysis of very low mercury (nano order) in solid and liquid samples in five minutes. The DMA-80 analyzer does not require any pre-treatment of the sample, unlike other analytical techniques which require dissolution or mineralization of the products to be analyzed. This device uses thermal decomposition followed by amalgamation of gold and detection of atomic absorption spectrometry according to USEPA (United States Environmental Protection Agency) method 7473 (Fig. 3).

Liquid or solid samples are introduced into the direct mercury analyzer after weighing. It is then dried in a stream of oxygen which passes through a quartz tube located inside a resistance furnace. The sample is then decomposed. The combustion gases are then decomposed in a catalytic column at $750^{\circ} \mathrm{C}$, where the halides and oxides are trapped. The remaining decomposition products are then transported to the gold amalgamator which selectively traps the mercury. The continuous flow of oxygen removes any residual gases or decomposition products. The heated amalgamator desorbs the mercury vapor to the measuring cells at the detector where the height of the peak absorbance is measured at $253.7 \mathrm{~nm}$ as a function of the mercury content (ng). The mercury concentration is read on a monitor screen (Azon et al., 2021; Adounkpe et al., 2021).

\section{Data Analysis}

A descriptive analysis via cartographic representations that reflect the reality of the distribution of mercury in the sedimentary space of Lake Ahéme on the one hand and through the visualization of the ANOVA test on the other hand was achieved. Additionally, ANOVA is done to assess the effect of sampling areas and other parameters on mercury concentration. Analysis of variance is a statistic used to estimate mean values by variances. This test applies when measuring one or more categorical explanatory variables. The one-way or one-way classification analysis of variance test is used here to compare the means of several items from random, simple and independent sample data. The test is performed either by comparing the observed Fisher value with the theoretical one, extracted from the Fisher table with a significance level of 0.05 or 0.01 or 0.001 for $\mathrm{k} 1$ and $\mathrm{k} 2$ of degrees of freedom; or by comparing the value of the probability $\mathrm{p}$ with a significance of $5 \%$ of $1 \%$ or $0.1 \%$.

\section{Assessment of Sediment Quality}

The ecological quality of the sampled sediments is assessed through:

1- The assessment of the geo-accumulation index according to the following formula: 


$$
\lg e O=\log 2\left(\frac{\mathrm{cm}}{1,5 x C f g}\right)
$$

Where:

- $\mathrm{Cm}$ corresponds to the measured mercury concentration

- Cfg to the geological concentration of mercury

- 1.5 the correction factor for the geochemical background (Nahli et al., 2016; Soussou et al., 2019

- the value of the geochemical background used for the present work is $56 \mu \mathrm{g} / \mathrm{kg}$ (Soussou et al., 2019)

2- and the assessment of the contamination factor, the formula of which is as follows:

$$
F C=\left(\frac{c m}{C f g}\right)
$$

$\mathrm{Cm}$ corresponds to the measured mercury concentration, $\mathrm{Cfg}$ is the geological concentration of mercury. (Sahli, 2012; Rubio et al., 2000)

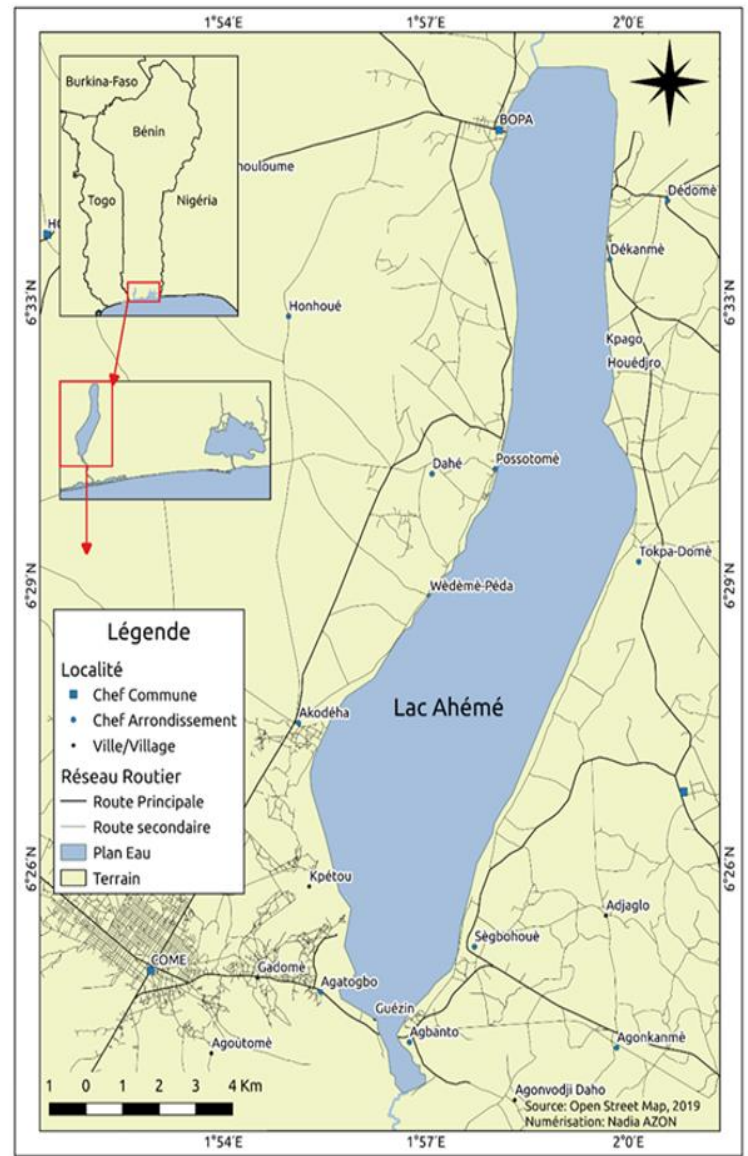

Fig. 1: Geographical location of Lake Ahémé (Azon et al., 2021)

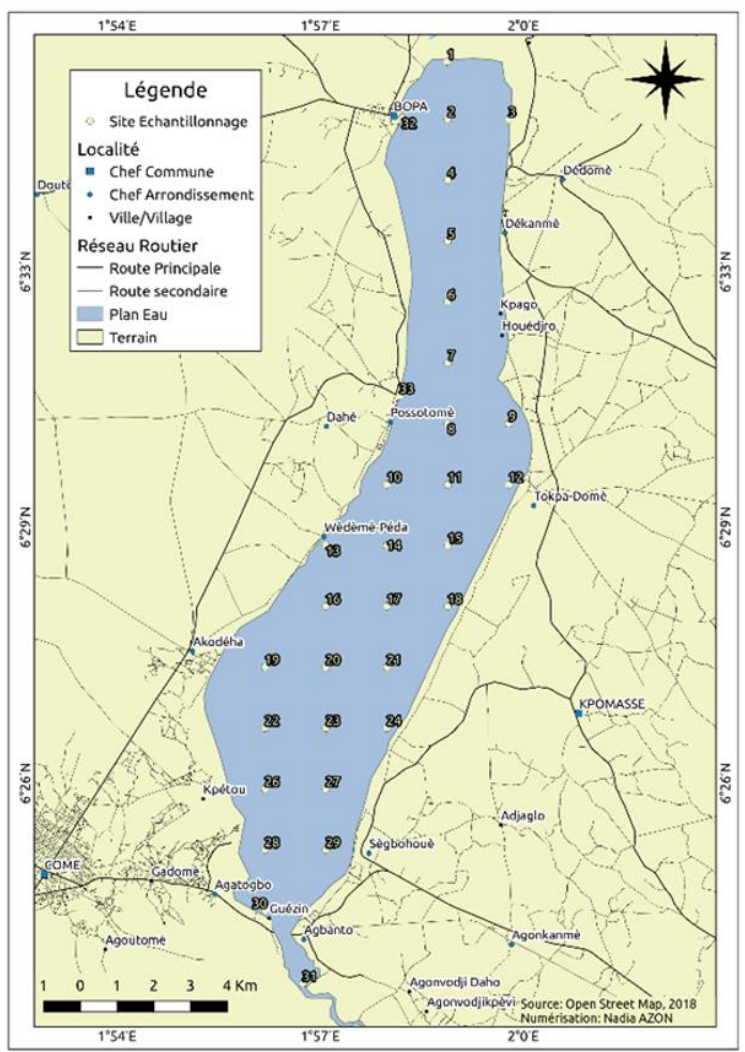

Fig. 2: Sediment sampling map on lake Ahémé (Azon et al., 2021)

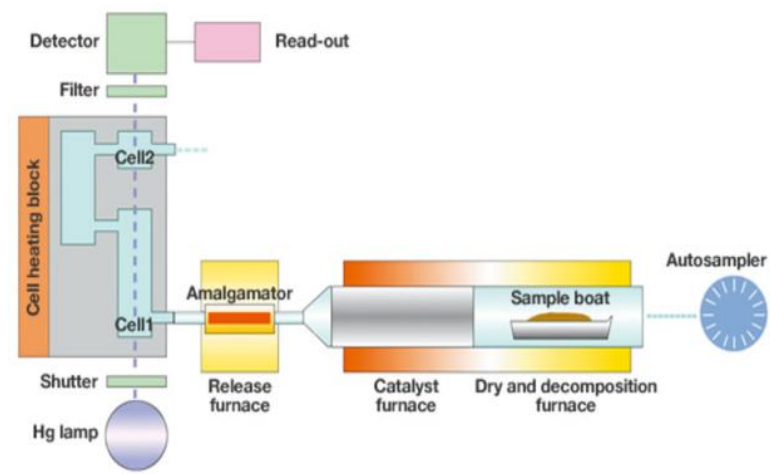

Fig. 3: Diagram of the operation of the direct mercury analyzer

\section{Results}

Figure 4 below shows the variation of the mercury concentration in the sedimentary space of Lake Ahémé in July 2018 and December 2019. These representations show that the distribution of mercury in the sediment depends on the period of the year.

Table 1 presents the statistical results of the ANOVA carried out on the physicochemical parameters of the sediments studied. From this analysis, it emerges that the variation of the sediment fraction and its organic matter constitution are strongly dependent on the sampling period with a significance rate $\mathrm{p}<0.001$. Moreover, the 
mercury concentration varies not only according to the sampled area but also according to the depth of the sampling site $(\mathrm{p}<0.05)$

Figure 6 shows the Igeo values for all the different samples taken. It reveals that sediments are not generally polluted. However, removing the correction factor for the geochemical background, the Fig. 7 reveal the existence of moderate pollution of the sediments of Lake Ahémé.

\section{Discussion}

\section{Spatial Distribution of Mercury in the Sedimentary Space of Lake Ahémé}

In 2018, the metal is more concentrated in the northern part then in the central part with levels of 109 and $132 \mu \mathrm{g} / \mathrm{Kg}$ respectively. This could be explained by an accumulation of metal in the silt zone of the lake during the heavy rainy season (July). In 2019, on the other hand, mercury is more concentrated in the central part with an average content of $162 \mu \mathrm{g} / \mathrm{Kg}$ then in the southern zone with an average highest concentration of $87 \mu \mathrm{g} / \mathrm{Kg}$. This could be explained by a migration of metallic pollution from the body of the lake to its downstream part during the low water period (December). This corroborates the observations made at Lake Nokoué during the recession period (Azon et al., 2021).

In addition, from the ANOVA representations (Fig. 5) there is a significant difference between the "center" zone and the "north" and between the "north" and the "south" in December 2019. Indeed, during the period of low water mercury pollution from the high latitudes is drained towards the lowest latitudes, hence the increased presence of the metal in the zone and in the south, unlike the north zone. On the other hand, in July 2018, there was no significant difference between the three zones of the lake. Thus, the mercury contamination of the sediments of Lake Ahémé in 2018 would be the result of discharges into lakes, runoff water in the rainy season. In fact, this water, by washing the soils crossed, also drains a certain metallic pollution which would enrich the watershed (Eblin et al., 2014; Assaad, 2014).

\section{Influence of the Parameters Measured on the Variation of the Mercury Content of the Sediments}

Table 1 presents the statistical results of the ANOVA carried out on the physicochemical parameters of the sediments studied. From this analysis, it emerges that the variation of the sediment fraction and its organic matter constitution are strongly dependent on the sampling period with a significance rate $\mathrm{p}<0.001$. Moreover, the mercury concentration varies not only according to the sampled area but also according to the depth of the sampling site $(\mathrm{p}<0.05)$. In fact, in hollow areas, organic matter and the fine sediment fraction sediment more easily, hence the strong presence of mercury, on the other hand, in shallow areas, the water current would more easily drain the metal through the particles.

By evaluating the interference effect of the categorical variables (Table 2), an interaction between the sampling period and the sampling area $(\mathrm{p}<0.03)$ emerges. In addition, the significant of the sampling area is always expressed with a rate $\mathrm{p}<0.05$.
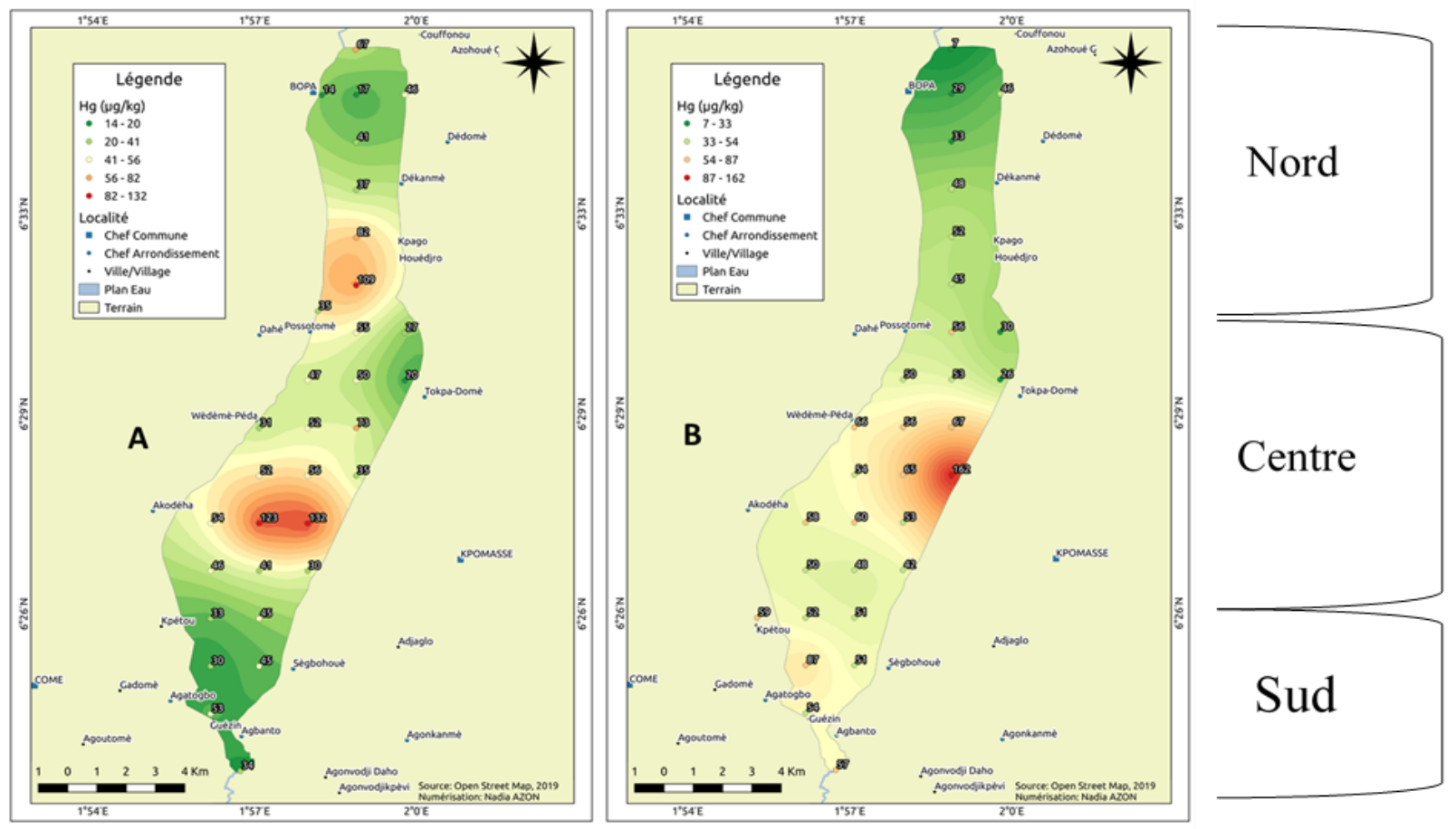

Fig. 4: Spatial distribution of sediment mercury in Lake Ahémé -July 2018 (A) -December 2019 (B) 
zone 追 Centre 追 Nord 官 Sud

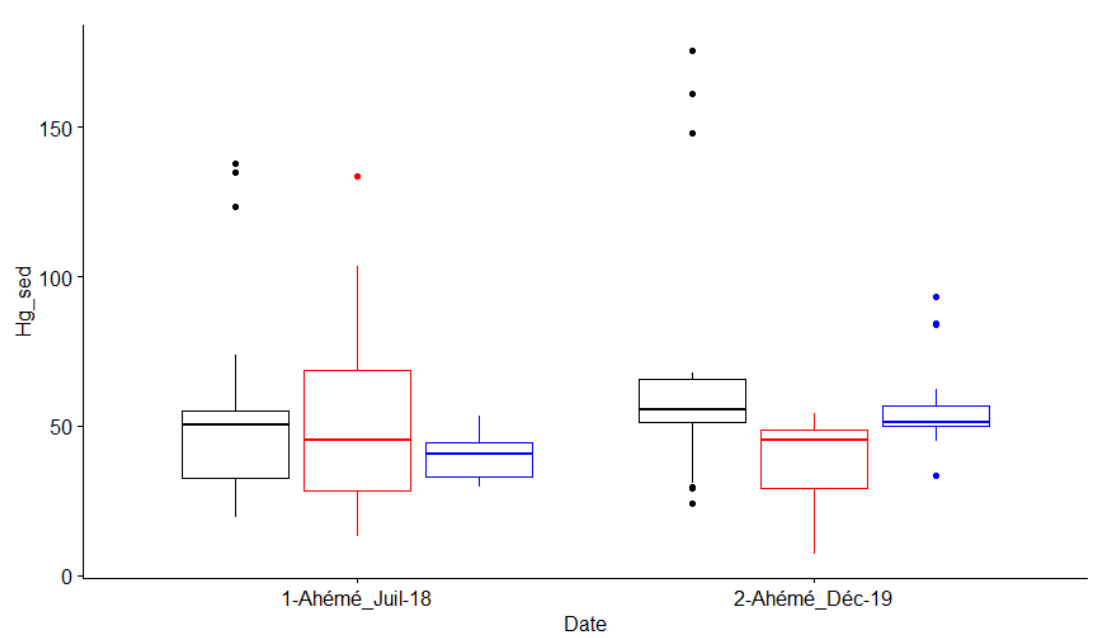

Fig. 5: Distribution of mercury in the different areas of Lake Ahémé between 2018 and 2019

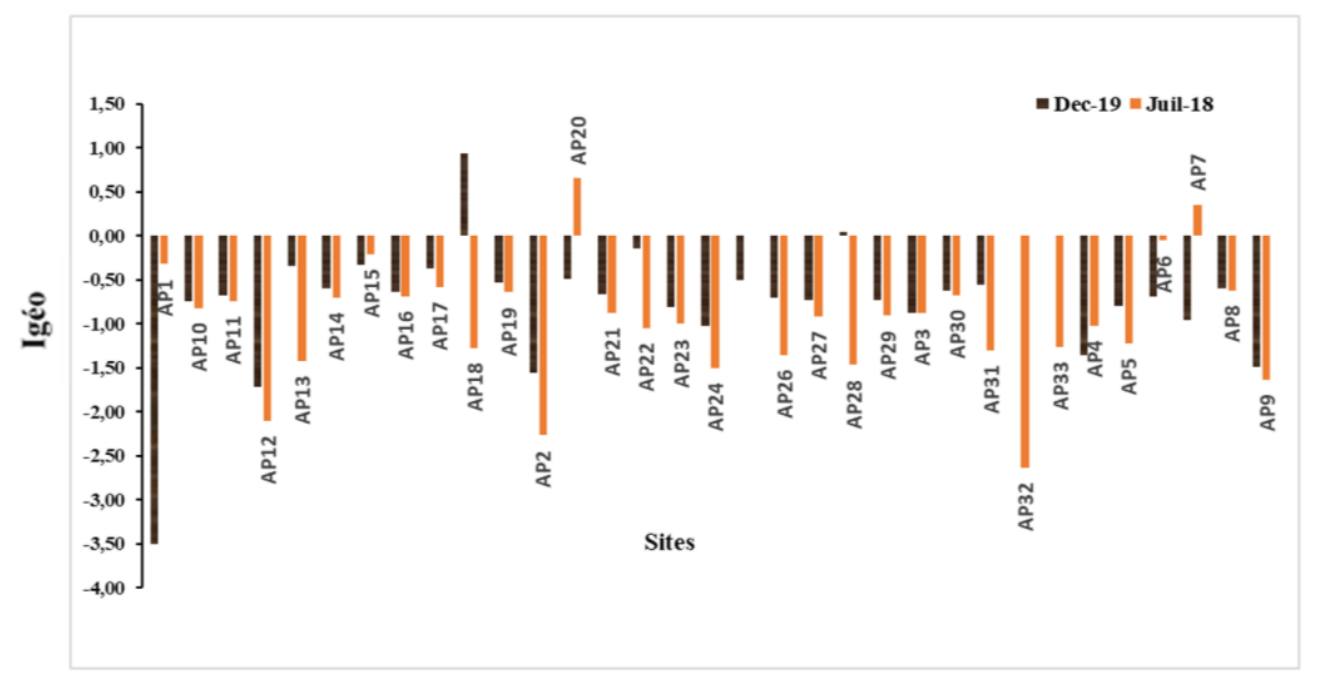

Fig. 6: Average Igéo in the sediments of Lake Ahéme in 2018-2019

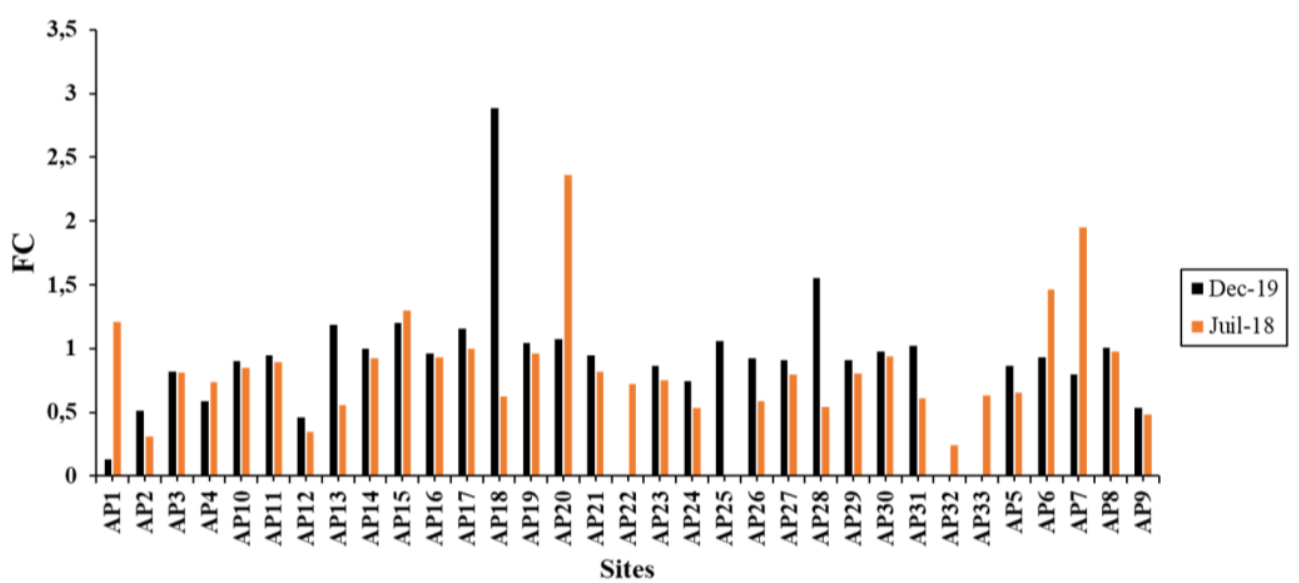

Fig. 7: Average CF in the sediments of Lake Ahéme in 2018-2019 
Table I: ANOVA test result

\begin{tabular}{lllllll}
\hline & Df & Sum Sq & Mean Sq & F value & $\operatorname{Pr}(>\mathrm{F})$ & \\
\hline Zone & 2 & 4454 & 2227 & 4.699 & 0.010261 & $*$ \\
date & 1 & 1739 & 1739 & 3.699 & 0.057011 &. \\
eH & 1 & 14 & 14 & 0.029 & 0.865761 & \\
Fract_Fine & 1 & 5546 & 5546 & 11.700 & 0.000774 & $* * *$ \\
pH & 1 & 1459 & 1459 & 3.078 & 0.081046 &. \\
Mo & 1 & 12707 & 12707 & 26.807 & $6 \mathrm{e}-07$ & $* * *$ \\
Profondeur & 1 & 4395 & 4395 & 9.271 & 0.002680 & $* *$ \\
\hline
\end{tabular}

Table 2: Effect result of the interactions of categorical variables

\begin{tabular}{lllllll}
\hline & Df & Sum Sq & Mean Sq & F value & $\operatorname{Pr}(>\mathrm{F})$ & \\
\hline Zone & 2 & 4454 & 2227 & 3.958 & 0.2077 & $*$ \\
Date & 1 & 1739 & 1739 & 3.091 & 0.08041 & $*$ \\
Zonne: Date & 2 & 6548 & 3274 & 5.817 & 0.00356 & $* *$ \\
\hline
\end{tabular}

\section{Ecological Quality of the Sediments Studied}

The calculation of the geo-accumulation indices (Fig. 6) indicates that the sediments studied on Lake Ahémé are the same pollution, except the AP18 sites in 2018; AP20 and AP7 in 2019, respectively located in the central and northern zone of the lake which has mercury contamination linked to geochemical background noise (Igeo $<0$ ).

By hiding the effect of background noise by considering the contamination factor, it appears that $83.87 \%$ of the sites studied in 2018 and $80.64 \%$ of those studied in 2019 are the same for any mercury pollution. The AP1, AP6, AP7, AP15 and AP20 sites in 2018 and the AP13, AP15, AP18, AP20, AP25 and AP28 sites in 2019 are moderately polluted with mercury $(1<\mathrm{FC}<6)$. The highest gradients are observed at the AP18 (FC $\approx 2.88)$ and AP20 (FC $\approx 2.35)$ sites in 2018 and 2019 respectively (Fig. 7).

\section{Conclusion}

This work was interested in the distribution of mercury in the sedimentary space of Lake Ahémé in 2018 and in 2019. Thus, from the results obtained, we retain that the concentration of mercury in the sedimentary environment of the lake varies according to the seasons. the year. It is linked to the runoff of leaching water from the soil during rainy periods. In the dry season, the amount of available mercury is drained downstream from the ecosystem. Furthermore, the presence of mercury in the sediment is dependent not only on the proportion of the fine sediment fraction, but also on the composition of the organic material sediment. It would therefore be appropriate, through metallic speciation, to evaluate the actual fraction of mercury present in the sediment.

\section{Acknowledgement}

The authors acknowledge the support from the Laboratory of Environmental Studies and Monitoring for the experimental analysis of mercury in sediments.

\section{Authors 'Contributions}

Adounkpe G. Julien: Designed the research project idea, supervised data collection and made correction on the draft of the paper.

Azon Nadia N.B: Did literature review, organized and collected the data, did laboratory work and drafted the paper.

Degila Hermione: Did the laboratory work along with Mrs. Azon as Prof Adounkpe team member.

Peace Hounkpe: did sediment data collection and data analysis.

\section{Ethics}

The authors claim ownership over the design of the research project idea and the data collected leading to this paper and confirm that this article has no ethical problem.

\section{References}

Adounkpe, J. G., Azon, N. B., Dégila, H. W., Hounkpe, P., \& Amoussou, R. (2021). Assessment of the Temporal and Spatial Variation of the Mercury Content of Lake Nokoué in Southern Benin Republic (West Africa). The Scientific World Journal, 2021. doi.org/10.1155/2021/5412785

Amoussou, E. (2010). Rainfall variability and hydrosedimentary dynamics of the watershed of the Mono-Ahémé-Couffo river-lagoon complex (West Africa). Single doctorate thesis, University of Burgundy, Dijon.

Assaad, A. (2014). Anthropogenic pollution of rivers: Spatio-temporal characterization and estimation of flows. Doctoral thesis. University of Lorraine. French. P.227.

Azon, N. N., Hounkpe, P., Adounkpe, J. G., Degila, H. W., \& Aina, M. P. (2021). Direct Mercury Analyzer (DMA) determination of mercury distribution in the sediments of lake Nokoué in Benin Republic-West Africa. International Journal of Biological and Chemical Sciences, 15(1), 306-316. doi.org/10.4314/ijbcs.v15i1.27

Chouti, W. K., \& Dèdjiho, L. A. (2017). Zinc toxicity and sequential extractio lake: A case study of. Research Journal of Chemical, 7(5), 23-30.

Dédjiho, A. C. (2014). Diagnostic study of chemical pollution of water bodies in the lagoon complex in southwestern Benin: Case of Lake AhéméGbèzoumè. s.1.: Unique doctoral thesis, University of Abomey-Calavi, 2014. 139p.

Dimon, F., Dovonou, F., Adjahossou, N., Chouti W., Mama D., Alassane A., Boukari M. (2014). Physicochemical characterization of Lake Ahémé (South Benin) and highlighting the pollution of sediments by lead, zinc and arsenic. s.1.: J. Soc. West-Afr. Chim. (2014), 037, 36-42. 
Eblin S.G., Sombo A.P, Soro G., Aka N, Kambiré O., Soro N. 2014. Hydrochemistry surface waters of the Adiaké region (south-eastern coast of Côte d'Ivoire). J. Appl. Biosci., 75: 6259-6271.

Nahli, A., Hebabaze, S., Iounes, N., Mohamed, B., \& Abderrahmane, C. (2016). Study of the metallic contamination of the surface sediments of the Oued Hassara after installation of the purification station (StEp) of Médiouna (Casablanca, Morocco). Rabat: Bulletin of the Scientific Institute, Life Sciences Section, 2016. 38, 1-14.

Rubio, B., Nombela, M. A., \& Vilas, F. (2000). Geochemistry of major and trace elements in sediments of the Ria de Vigo (NW Spain): An assessment of metal pollution. Marine pollution bulletin, 40(11), 968-980.

doi.org/10.1016/s0025-326x(00)00039-4.
Roche International. (2000). Study of the Southern Benin Water Plan Development Project: Environment, Waters and Forests, Volume 2- Volume IV.

Sahli, L. (2012). Study of the behavior of some flora and fauna species in aquatic ecosystems with respect to metallic trace elements by bioassays. s.l., Doctoral thesis, Mentouri University of Constantine, 2012. 262p.

Soussou, Y. I., Akesse, D. P. V., Kouame, K. V. Y., Dopé, A. C., \& Yapo, O. B. (2019). Assessment of trace metal contamination of sediments in Lake Kossou (Côte d'Ivoire). s.l, J. Chem. Organic. Phy. Sci. Sec., 2019. 3, 217-229. 